\title{
HNRNPK Gene
}

National Cancer Institute

\section{Source}

National Cancer Institute. HNRNPK Gene. NCI Thesaurus. Code C150258.

This gene is involved in binding to poly-cytidine sequences in pre-mRNA and singlestranded DNA. 